\title{
A Primer on the Empirical Identification of Government Spending Shocks
}

\author{
Kristie M. Engemann, Michael T. Owyang, and Sarah Zubairy
}

\begin{abstract}
The empirical literature on the effects of government spending shocks lacks unanimity about the responses of consumption and wages. Proponents of shocks identified by structural vector autoregressions (VARs) find results consistent with New Keynesian models: consumption and wages increase. On the other hand, proponents of the narrative approach find results consistent with neoclassical models: consumption and wages decrease. This paper reviews these two identifications and confirms their differences by using standard economic series. It also uses alternative measures of government spending, output, and the labor market and shows that, although there are minor fluctuations within each identification, the disparate results between the two are robust to the alternative measures. However, under the structural VAR approach, the authors find some differences between the responses to federal and state/local government spending. (JEL C32, E62)
\end{abstract}

Federal Reserve Bank of St. Louis Review, March/April 2008, 90(2), pp. 117-132.

4

any textbook macroeconomic models contain predictions about the effects of fiscal policy. Unfortunately, these models lack unanimity about the response of some variables to surprise increases in government spending. For example, neoclassical models and New Keynesian models have opposing predictions regarding the direction of the effect of government spending shocks on consumption and real wages. Neoclassical models predict that, when a government spending shock hits the economy, households, facing the prospect of higher taxes, experience a negative wealth effect. Households respond by lowering their consumption and leisure. The increased labor supply from households also leads to a fall in real wages for any given labor demand. New Keynesian models instead predict that consumption and real wages rise in response to a positive government spending shock. These models often contain features that generate countercyclical markups (e.g., nominal price rigidities or deep habits [see Ravn, SchmittGrohé, and Uribe (2006)]), which in turn cause labor demand to shift up in response to a government spending shock. This results in rising wages and higher consumption for the households due to substitution effects or the presence of credit constraints.

The empirical literature has been unable to resolve this controversy. Depending on the nature of the identifying assumptions, the empirical literature finds disparate stylized facts regarding the responses of some variables to government spending shocks. The responses of consumption and wages, in particular, can take on different signs depending on the assumptions used to identify fiscal policy shocks. The structural vector autoregression (VAR) approach that Blanchard and Perotti (2002) and Fatás and Mihov (2001) use to identify government spending shocks yields a positive response for output, consump-

Kristie M. Engemann is a senior research associate and Michael T. Owyang is a research officer at the Federal Reserve Bank of St. Louis. Sarah Zubairy is a PhD candidate in economics at Duke University. The authors thank Riccardo DiCecio, Valerie Ramey, Bob Rasche, and Howard Wall for suggestions and useful conversations. Heidi Beyer-Powe provided research assistance.

(C) 2008, The Federal Reserve Bank of St. Louis. Articles may be reprinted, reproduced, published, distributed, displayed, and transmitted in their entirety if copyright notice, author name(s), and full citation are included. Abstracts, synopses, and other derivative works may be made only with prior written permission of the Federal Reserve Bank of St. Louis. 
tion, and real wages. On the other hand, the narrative approach introduced by Ramey and Shapiro (1998) uses military spending events as a proxy for exogenous shocks to government spending. This approach typically finds that, in response to these large military buildups, output rises but consumption and real wages fall. ${ }^{1}$

A few recent papers (e.g., Ramey, 2006, and Perotti, 2007) have reenergized this debate regarding the responses of economic variables under different identification schemes. One concern is that the structural VAR approach may not be identifying exogenous innovations to fiscal policy. That is, the timing restrictions used in structural VARs may identify shocks that are anticipated by economic agents. This would confound the econometrician's ability to disentangle the effects of fiscal policy. This results in responses that are biased by some omitted predictors. ${ }^{2}$ Criticism can also be levied on the narrative approach. This methodology treats all of the large fiscal episodes equally rather than allowing for some variation in the size and shape of the response.

In this paper, we review some of the findings in this empirical literature on government spending. In addition, we are interested in distinguishing between shocks to total government spending and disaggregated measures such as federal government spending and state and local government expenditures. A third issue we address is whether the responses of macro variables are robust to alternative measures of data: for example, using real personal income (PI) as a measure of real economic activity instead of real gross domestic product (GDP) or using employment instead of hours worked. Our findings suggest that the choice of macro variables in the VAR is important. For instance, we find that employment is generally more responsive than hours

\footnotetext{
1 In this growing literature, other researchers have considered the effect of government spending on different economic variables. For example, Tavares and Valkanov (2003) examine the effect of fiscal policy on asset prices and Favero and Giavazzi (2007) examine the effect on interest rates.

2 We may view these biases as similar to the manner in which the price response to monetary shocks exhibits a price puzzle when commodity prices are omitted (Sims, 1992). Agents may have information about the economy that would be outside the VAR. Thus, the identified monetary shocks might be mixing exogenous shocks with an endogenous response to omitted variables.
}

and that personal income is less responsive than GDP to a total government spending shock.

The remainder of the paper is organized as follows. The next section reviews two of the identification procedures common to the literature on fiscal policy. It first outlines the identification of the structural VAR based on timing restrictions and then considers the dummy-variable identification using the military spending dummies defined by Ramey and Shapiro (1998). The third section reviews the data used in the estimation. In particular, it discusses differences across the government spending series and suggests alternative measures of output and the labor market. The fourth section presents the results from the estimation using various identifications and specifications.

\section{MODEL AND IDENTIFICATION}

Since Sims (1980), the VAR has become a staple in the empirical literature on monetary, technology, and fiscal policy shocks. In each case, for VARs to be useful for policy analysis, they require some restrictions to transform the reducedform residuals into structural innovations. With these structural innovations in hand, one can then determine the responses of non-policy variables (e.g., output, prices) to the shock in question. In this section, we consider two common identifying assumptions used in the empirical literature on fiscal policy: (i) a structural VAR approach that uses timing restrictions (Blanchard and Perotti, 2002), which assumes that innovations to government spending occur prior to the determination of other variables, and (ii) the narrative approach that uses military spending dummy variables (Ramey and Shapiro, 1998) as a proxy for exogenous shocks to government spending. ${ }^{3}$

\section{Timing Restrictions}

Consider the following reduced-form $p$-order VAR

\footnotetext{
3 Mountford and Uhlig (2005) and Pappa (2005) posit an alternative identifying assumption using sign restrictions. The findings for these identifications are similar to those of the structural VAR literature and are not considered here.
} 


$$
y_{t}=B(L) y_{t-1}+\varepsilon_{t},
$$

where $y_{t}$ is the $n \times 1$ vector of economic variables including government spending, $B(L)$ is a polynomial of lag operators, and $\varepsilon_{t} \sim N(0, \Sigma)$ are reduced-form innovations. The structural representation of the VAR can be written as

$$
A_{0} y_{t}=A(L) y_{t-1}+v_{t} .
$$

The objective, then, is to uncover the structural innovations, $v_{t}$, defined by an orthonormal rotation of the reduced-form residuals:

$$
v_{t}=A_{0} \varepsilon_{t}
$$

where $A_{0}^{-1} \Omega A_{0}^{-1^{\prime}}=\Sigma, v_{t} \sim N(0, \Omega)$, and the covariance matrix $\Omega$ of the structural innovations is diagonal. The well-known problem in the literature on structural VARs is that $A_{0}^{-1} \Omega A_{0}^{-1^{\prime}}=\Sigma$ does not define a unique rotation. The matrix $A_{0}$ contains $n^{2}$ coefficients, which need to be determined to identify a unique rotation. However, the system $A_{0}^{-1} \Omega A_{0}^{-1^{\prime}}=\Sigma$ provides only $[n(n+1)] / 2$ parameters to tie down elements of $A_{0}$. To identify the true structural innovations, one must place some restrictions on the system. If restrictions can be placed on $A_{0}$ itself, one would need at least [ $n(n$ -1)]/2 binding restrictions for identification. ${ }^{4}$ Often, theory does not provide enough assumptions to identify the full complement of parameters in $A_{0}$. In such cases, one might choose to place fewer restrictions on the system and identify only a particular shock (e.g., a single row of $A_{0}$ ).

These restrictions can be of several forms. Exclusion restrictions assume that some variables do not respond contemporaneously to the shock. These restrictions are implemented by setting elements of $A_{0}$ to zero and generally imply a causal ordering across the variables (e.g., the federal funds rate responds to innovations in output but not vice versa). Sign restrictions identify the shock by imposing the direction of the impulse responses of certain variables at predefined horizons. For example, we can identify contractionary

\footnotetext{
4 Weaker identifying assumptions may require more than $[n(n-1)] / 2$ restrictions (see Paustian, 2007).
}

monetary shocks by restricting the resulting impulse responses of the federal funds rate (positive) and inflation rate (negative) at short horizons. ${ }^{5}$ Forecast-error-variance restrictions identify the shocks through their relative power in explaining fluctuations in certain economic variables. These types of restrictions are particularly useful if theory indicates that the structural innovation should be neutral or dominant at long horizons. ${ }^{6}$

The timing identification involves the assumption that government spending is determined before the realizations of output and any other economic variables in quarterly data. Essentially, this assumption presumes that all other variables have no contemporaneous impact on government spending. This is accomplished by ordering government spending first in the VAR and identifying the matrix $A_{0}^{-1}$ as the Cholesky decomposition of $\Sigma$. The fiscal shock, then, is represented by the first row of the rotation matrix $A_{0}$.

\section{Defense Spending Dummies}

Identification of fiscal policy by means of the narrative approach is conducted in a similar framework as the timing restrictions outlined above. ${ }^{7}$ In this case, however, the VAR in equation (1) is augmented by a series of dummy variables representing the timing of large military buildups:

$$
y_{t}=B(L) y_{t-1}+C(L) d_{t}+\varepsilon_{t},
$$

where $d_{t}$ is the period- $t$ realization of the military spending dummy having an effect on the variables of interest at, say, $q$ lags and both $B(L)$ and $C(L)$ are lag polynomials of possibly different orders. ${ }^{8}$ The effect of fiscal policy is then computed as the impulse response to the military spending dum-

5 See Uhlig (2005) for implementation.

${ }^{6}$ For example, Faust (1998) identifies monetary shocks by assuming they have no long-run effect on output. Similarly, Francis, Owyang, and Roush (2007) identify technology shocks by assuming they are the largest contributor of labor productivity volatility.

7 Ramey and Shapiro (1998) estimate a two-variable version of the fiscal policy dummy. Edelberg, Eichenbaum, and Fisher (1999) extend the analysis to a VAR framework.

8 We use military dummies and military spending dummies interchangeably. 


\section{Figure 1}

\section{U.S. Government Spending Growth Rate (quarter/quarter percent change)}

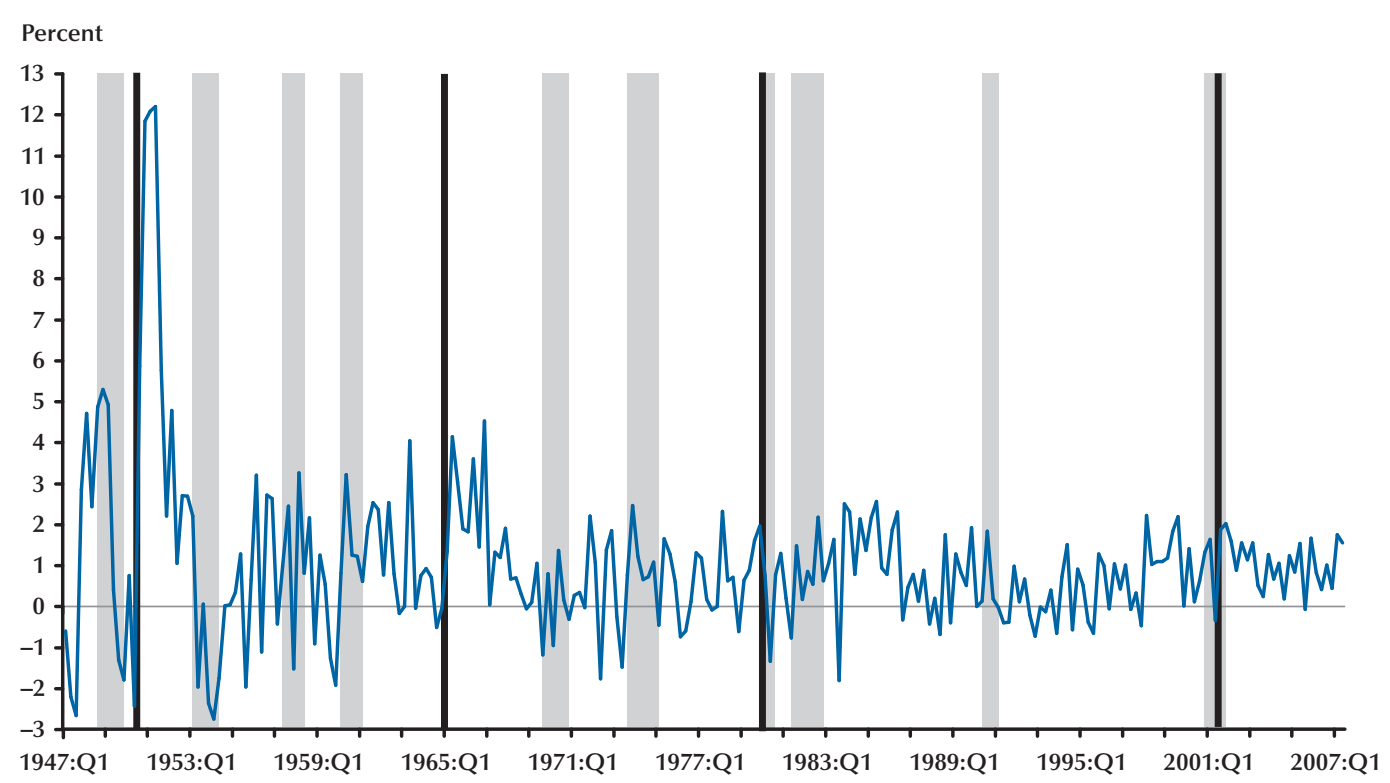

NOTE: Black bars indicate Ramey and Shapiro military buildup dates; gray shaded areas indicate NBER recession dates. The government spending series used is real government consumption expenditures and gross investment (seasonally adjusted, annual rate [SAAR]).

mies. The $k$-step-ahead response to the military shock is defined by the coefficient of $L^{k}$ in the expansion of $(I-B(L) L)^{-1} C(L)$.

Ramey and Shapiro's (1998) series of military spending dummies is constructed similarly to Romer and Romer's (1994) series of monetary policy innovations. While Romer and Romer consult the transcripts from FOMC meetings, Ramey and Shapiro use historical accounts and Business Week to identify periods in which the private sector revised upward their forecasts of future government spending. ${ }^{9}$ Given their definition of fiscal spending shocks, Ramey and Shapiro (1998) identify four episodes in the post-World War II period that qualify as exogenous shocks to government spending. ${ }^{10}$ The black vertical

9 Romer and Romer (2007) employ a similar narrative method to identify fiscal shocks, namely, tax shocks. They examine news, speeches of government officials, and other government documents.

${ }^{10}$ Ramey and Shapiro (1998) originally identified three episodes: the Korean War, the Vietnam War, and the Carter-Reagan buildup. lines in Figure 1 depict these dates, along with the growth rate in government spending and the recessions (as defined by the National Bureau of Economic Research; NBER) for the period 1947:Q1 to $2007:$ Q3. ${ }^{11}$

\section{DATA}

In addition to identification assumptions, the choice of variables included in the regression can affect the results. In particular, the choice of the government spending variable can significantly alter the conclusions drawn. Here, we discuss alternative government spending series. In

Ramey (2006) and Eichenbaum and Fisher (2005) extend the sample by adding the post-9/11 buildup.

${ }^{11}$ Other papers have used slightly different versions of the military dummies. For example, Burnside, Eichenbaum, and Fisher (2004) relax the restriction of responses to the military dummies in all episodes to have the same size and allow the fiscal episodes to have different intensities. 


\section{Figure 2}

\section{U.S. Government Spending}

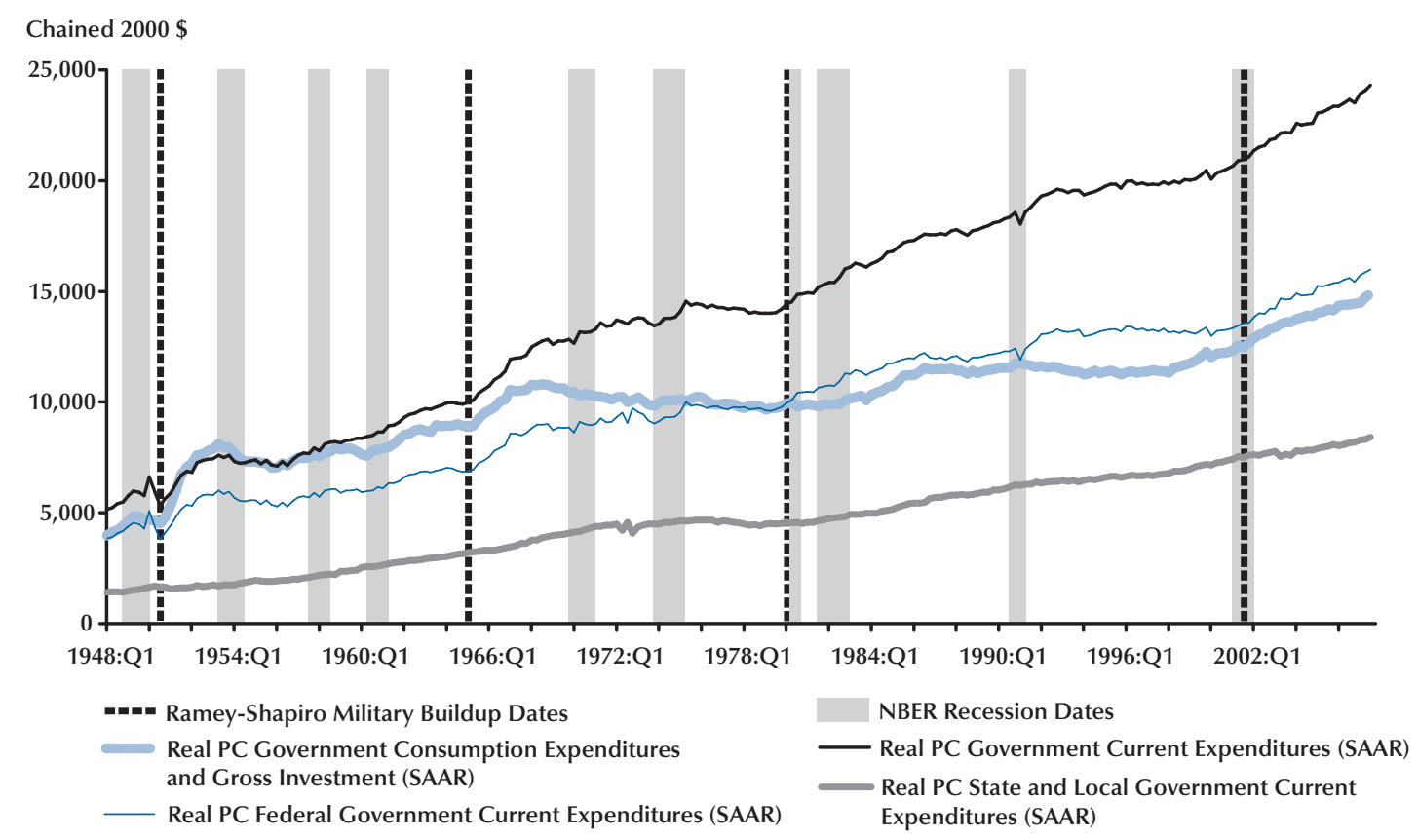

NOTE: PC is per capita. To obtain per capita series, the original series were divided by the civilian labor force.

addition, we outline some of the possible economic data that can be used to measure the effect of fiscal policy.

\section{Government Spending}

Not surprisingly, the effect of an innovation to government spending depends on one's definition of government spending. The government spending series frequently used in the literature with timing restrictions is real per capita government consumption expenditures and gross investment. This series includes federal, state, and local expenditures. Figure 2 shows how the latter two components have increased in recent years, both in per capita levels and as a fraction of total government spending. In addition, the figure depicts the differences in tax and transfer payment policies over time.

Although this might suggest a rise in the importance of state and local spending, a few qualifications must be noted. First, many states and municipalities have balanced budget requirements. The degree to which these requirements are enforced varies across states (Wagner and Sobel, 2006), which may suggest a different level of fiscal flexibility for state and local spending versus federal spending. Second, innovations to state and local government spending may be more likely to be anticipated. This is one of the primary motivations for Ramey and Shapiro's use of military buildups as a proxy for unanticipated fiscal shocks.

In light of these issues, we consider a few alternative government spending series. ${ }^{12}$ The first is real per capita government consumption expenditures and gross investment (G1), as the

\footnotetext{
12 Other papers have also considered the effects of different types of fiscal policy. For example, Fatás and Mihov (2001) consider deficits. Rotemberg and Woodford (1992) identify fiscal policy using military purchases as the government spending variable. Perotti (2004) considers the effects of government consumption versus government investment. Perotti (2007) differentiates between expenditures on government goods and outlay toward government employees.
} 
literature suggests. ${ }^{13}$ We also consider G1 net of gross investment (per capita real government current expenditures, G2) and G2 net of state and local spending (per capita federal government real current expenditures, G3). ${ }^{14}$

\section{Economic Variables}

We include a number of variables that typically appear in both empirical and theoretical models. These include output, consumption, investment, hours, and the real wage. ${ }^{15,16}$ The latter four variables reflect private sector contributions; government contributions to these variables are either modeled explicitly or are embedded in government spending. Real GDP, real nondurables and services consumption, and real investment and durables consumption are expressed in per capita terms. ${ }^{17}$ We then perform some additional experiments, for example, replacing hours with employment. ${ }^{18}$

Much of the disparity between the two identification schemes can be highlighted by a comparison of the responses of consumption and the real wage to various identified spending shocks. In addition to these two responses, we measure the effect of government spending shocks on various components of output. Although most other papers focus on breaking down output into con-

\footnotetext{
${ }^{13}$ Government consumption expenditures and gross investment is defined by the Bureau of Economic Analysis (BEA) as the value of services produced by government, measured as the purchases made by government on inputs of labor, intermediate goods and services, and investment expenditures. Government consumption expenditures includes compensation of government employees, consumption of fixed capital, intermediate purchases of goods and services less sales to other sectors, and own-account production of structures and software: www.bea.gov/glossary/glossary.cfm?letter=G.

${ }^{14}$ Current expenditures are consumption expenditures plus current transfer payments, interest payments, and subsidies.

${ }^{15}$ For details on the data series we used, see the data appendix.

16 The real wage variable used here is the real product wage. The consumption wage, which may be substituted in other studies, is the nominal wage deflated by the GDP deflator.

17 To obtain per capita series, we divided by the total civilian labor force. For every series in real terms (except real wage), we deflated the nominal series by the GDP implicit price deflator.

${ }^{18}$ Hours and employment have some obvious differences in the nature of their business cycle fluctuations. However, the hours series may be unavailable for some applications (e.g., transition country analyses).
}

sumption and investment, we also consider an alternative decomposition including PI, corporate taxes, and government transfers. Simple GDP accounting yields the following:

$\mathrm{GDP} \simeq \mathrm{PI}-$ transfers $+\left[\begin{array}{c}\text { corporate taxes } \\ \text { indirect business tax } \\ \text { retained earnings } \\ \text { Social Security } \\ \text { depreciation }\end{array}\right]-\left[\begin{array}{c}\text { net income from abroad } \\ \text { net interest }\end{array}\right]$.

This decomposition may allow us to determine how differences in the composition of the government spending shock affect components of the output portfolio.

\section{EMPIRICAL RESULTS}

In this section, we report the resulting impulse responses to fiscal innovations identified from the different methods described above. Each empirical model with timing restrictions is a VAR(4) with a constant and linear time trend estimated at a quarterly frequency with the logs of the variables listed. In the dummy-variable approach, each equation includes four lags of the endogenous variables and the Ramey and Shapiro dummy variables are entered with lags 0 to 6 . The data range from 1948:Q1 to 2007:Q2. Each case varies slightly as we alter the decomposition of output. The point values of the impulse responses are accompanied by their corresponding 95 percent confidence intervals. ${ }^{19}$

\section{Baseline Results}

Figure 3 depicts the baseline case estimated with GDP, consumption, hours, investment, and real wages. The first three columns of responses correspond to different identifications for fiscal spending using the timing restrictions. The first column shows the responses of these variables to a one-standard-deviation increase to G1. The second column presents the impulse responses to a similar shock to G2. The third column presents the responses to G3 in the baseline model. In

\footnotetext{
${ }^{19}$ Confidence intervals for each structural VAR are computed analytically. For the VARs with the military dummies, we use bootstrapped confidence intervals.
} 
Engemann, Owyang, Zubairy

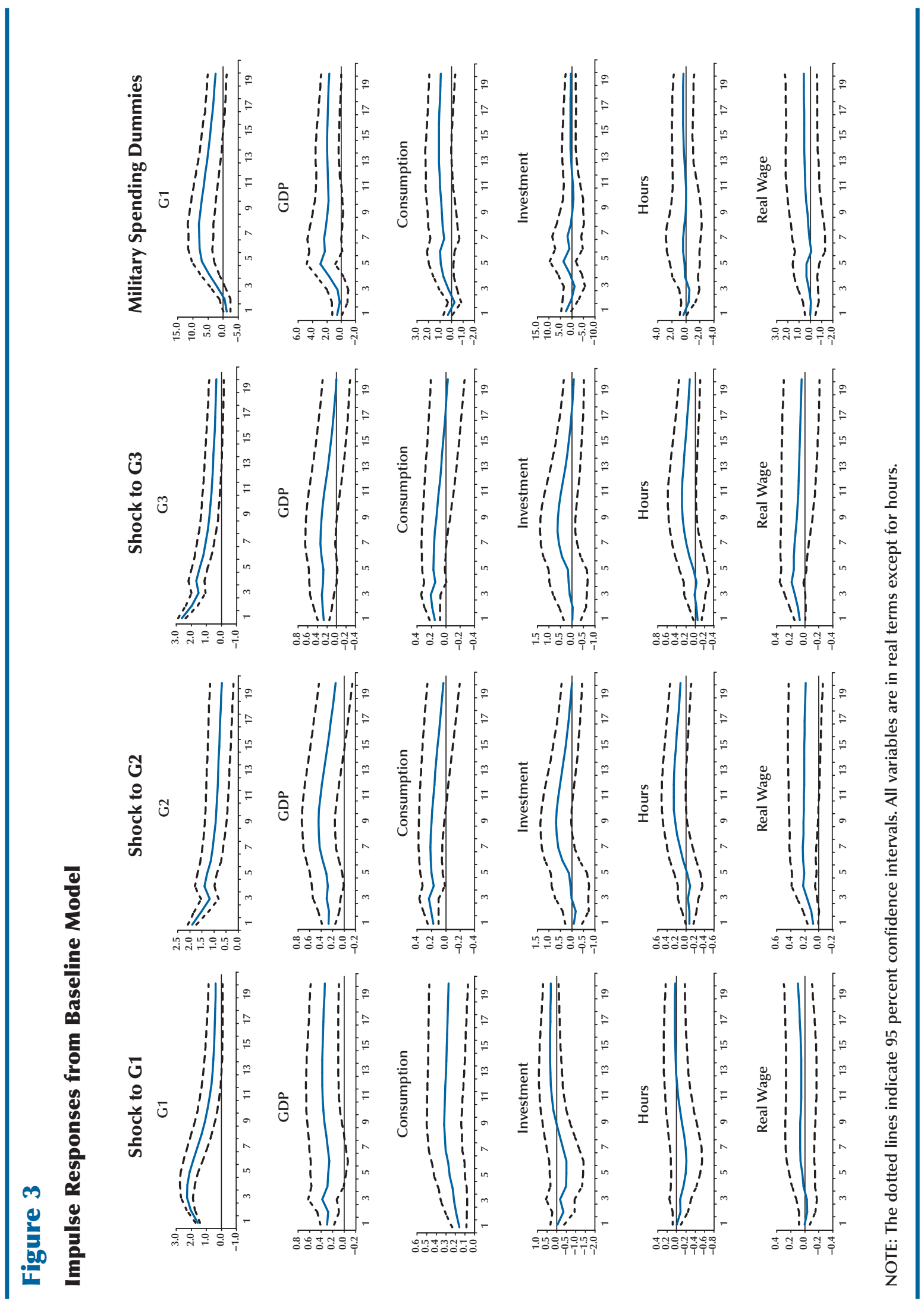


this case, we isolate the impact of federal versus state and local spending. The last column depicts the impulse responses to the military dummies using G1 as the measure of government spending.

For each structural VAR, the fiscal policy shock raises GDP and government spending on impact. The hours and investment responses are weakly negative on impact; however, these effects are statistically insignificant at all horizons. ${ }^{20} \mathrm{We}$ find, as does the recent literature, that there are differences between the responses of consumption and real wage across identifications. A shock to any of the three spending variables produces a positive response in consumption at all horizons except for the last four periods of the G3 identification. The response in the real wage is positive for the G2 and G3 identifications but initially negative for the G1 identification. ${ }^{21}$ On the other hand, the responses of consumption and the real wage to the military dummies are statistically insignificant; but the point estimate is slightly negative on impact for the real wage (for the first two periods), positive for consumption for the first period, but negative for consumption for the second.

\section{Hours versus Employment}

The canonical macroeconomic models typically contain predictions about hours. However, in some cases of interest to econometricians, hours data may be unavailable. Employment data can then be used as an alternative to hours data. To demonstrate the similarities and differences between the empirical responses of these two series, we reestimate the VARs and replace hours with employment in the baseline specification. ${ }^{22}$

\footnotetext{
${ }^{20}$ These results may differ slightly across the literature depending on which investment series is used. Ramey (2006), for example, uses gross domestic investment and finds a stronger response to government spending. Fatás and Mihov (2001) estimate disaggregated investment responses. They find residential investment rises and nonresidential investment falls in response to a government spending shock in a structural VAR.

${ }^{21}$ The point estimate of the real wage response is positive but statistically insignificant for the government spending identifications. This result is consistent with other studies.

${ }^{22}$ Using employment instead of hours may change the theoretical conclusions of some macro models. Differences in the predictions might be attributed to differences between labor usage at the extensive versus the intensive margins.
}

We use the same four identifications of fiscal policy and the same set of economic variables described in the previous specification. The responses of these other variables, as shown in Figure 4, remain qualitatively similar to those from the baseline specification with hours. The response of employment, however, differs slightly from that of hours. Based on the point responses, employment does seem more responsive to both government spending (except G1) and the military dummies. ${ }^{23}$ Also, both employment and hours seem relatively more responsive to G3 than consumption and the real wage but not GDP or investment.

We are interested in determining whether the sensitivity of employment to government spending is attributable to differences in government versus private hires. We can accomplish this by replacing employment with private employment. These results are shown in Figure 5. Here, the responses of private employment more closely match the responses displayed in Figure 4. It seems that the major component of the weak increase in employment seen in Figure 4 is the rise in private not government hires.

\section{Personal Income versus GDP}

The output measure used in most fiscal policy regressions is GDP. However, in some cases, an equivalent measure of output may not be available at a high frequency (e.g., for U.S. states). One alternative to GDP is PI. Figure 6 shows the responses of the baseline model in which GDP has been replaced by real per capita PI. Of note are the responses to shocks to G1 and G3. In the first case depicted in the first column of Figure 6, the response of PI is qualitatively similar to GDP but shifted downward. That is, the impact response of PI to a shock to G1 is smaller than that for GDP. However, when a shock to G3 is isolated, the impact responses of GDP and PI have similar magnitudes. The responses of PI and GDP to an innovation in the military spending dummy are

\footnotetext{
${ }^{23}$ One difference between the two series is that hours measures action at the intensive margin while employment measures the extensive margin (see Fang and Rogerson, 2007).
} 


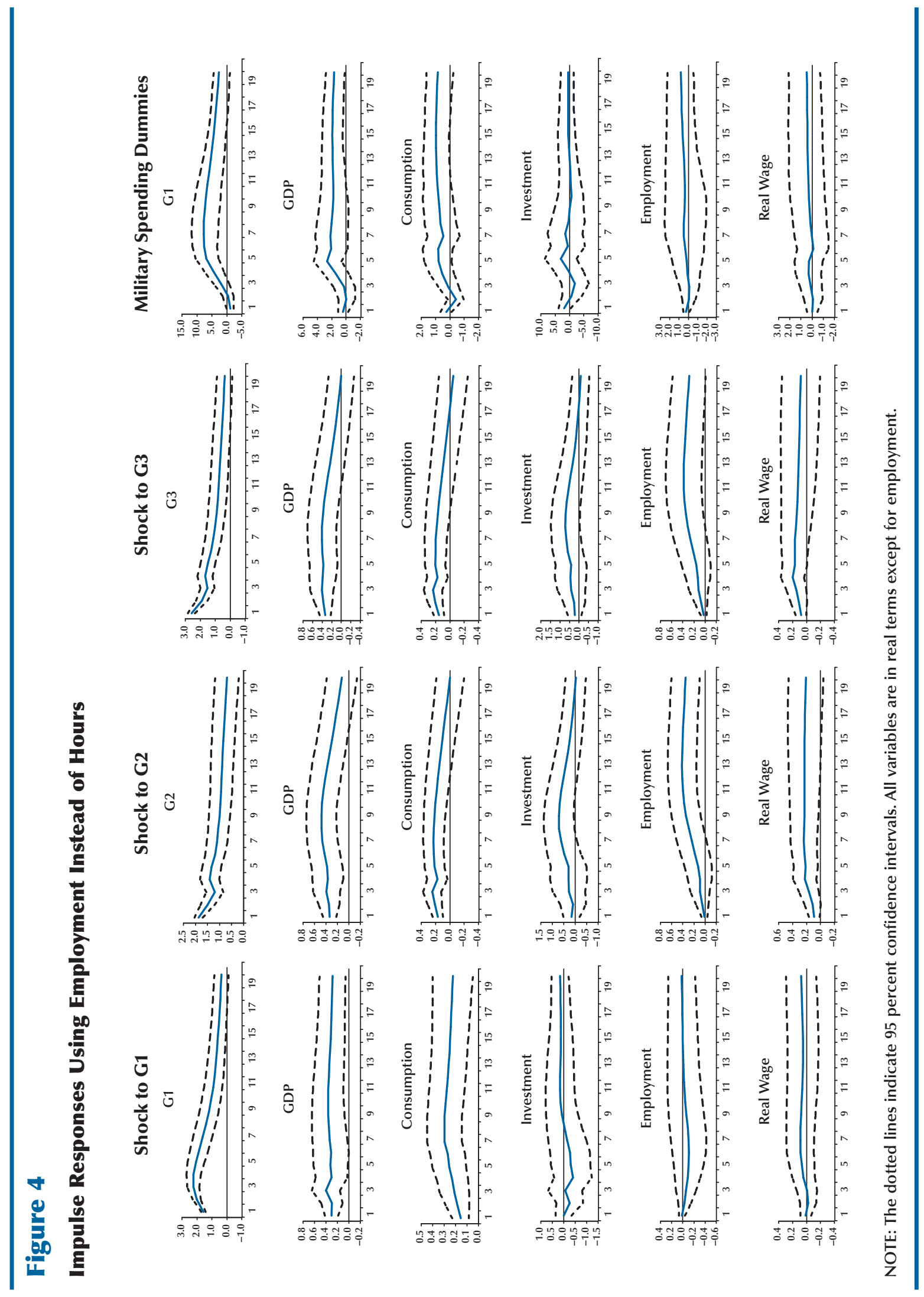




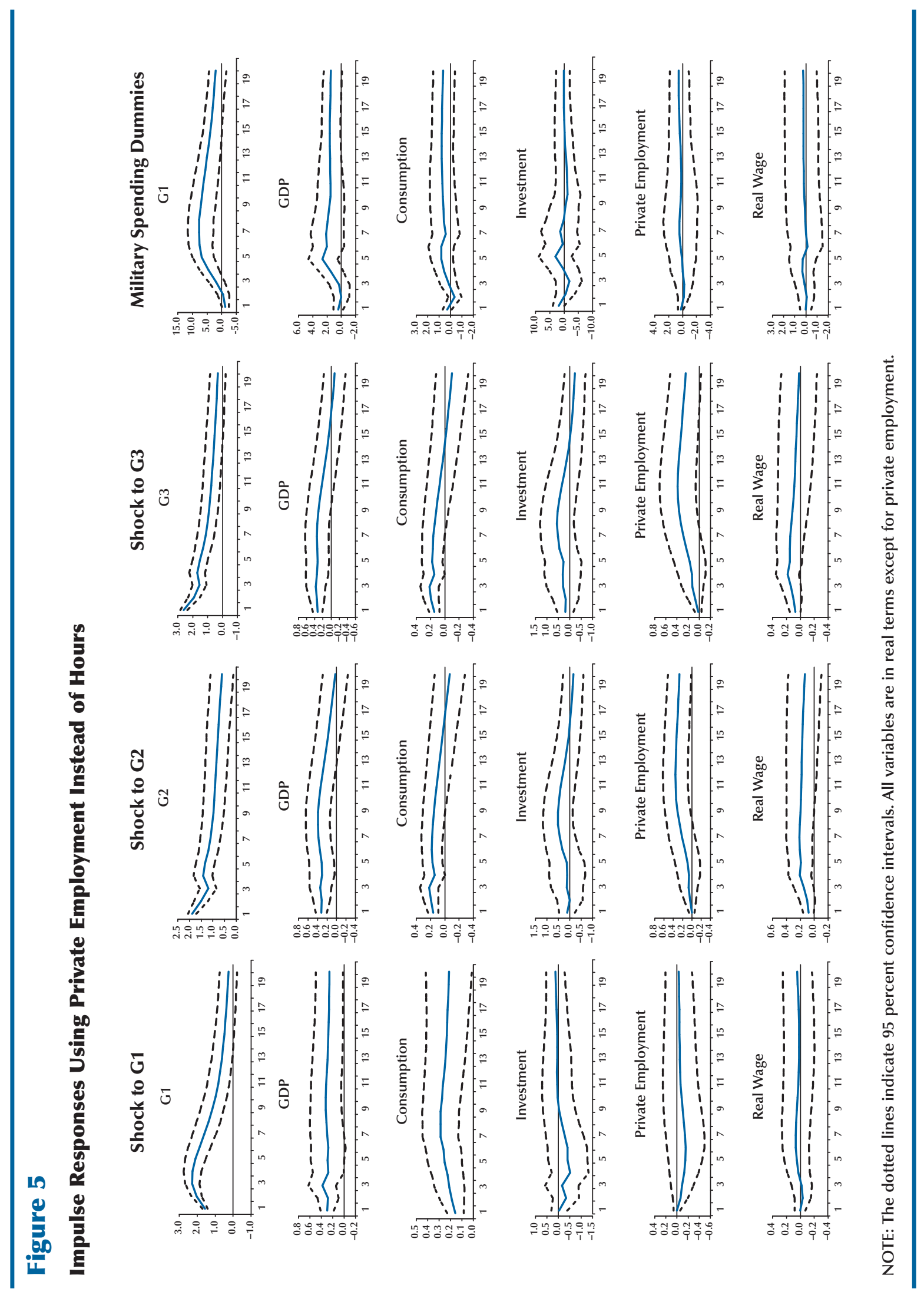




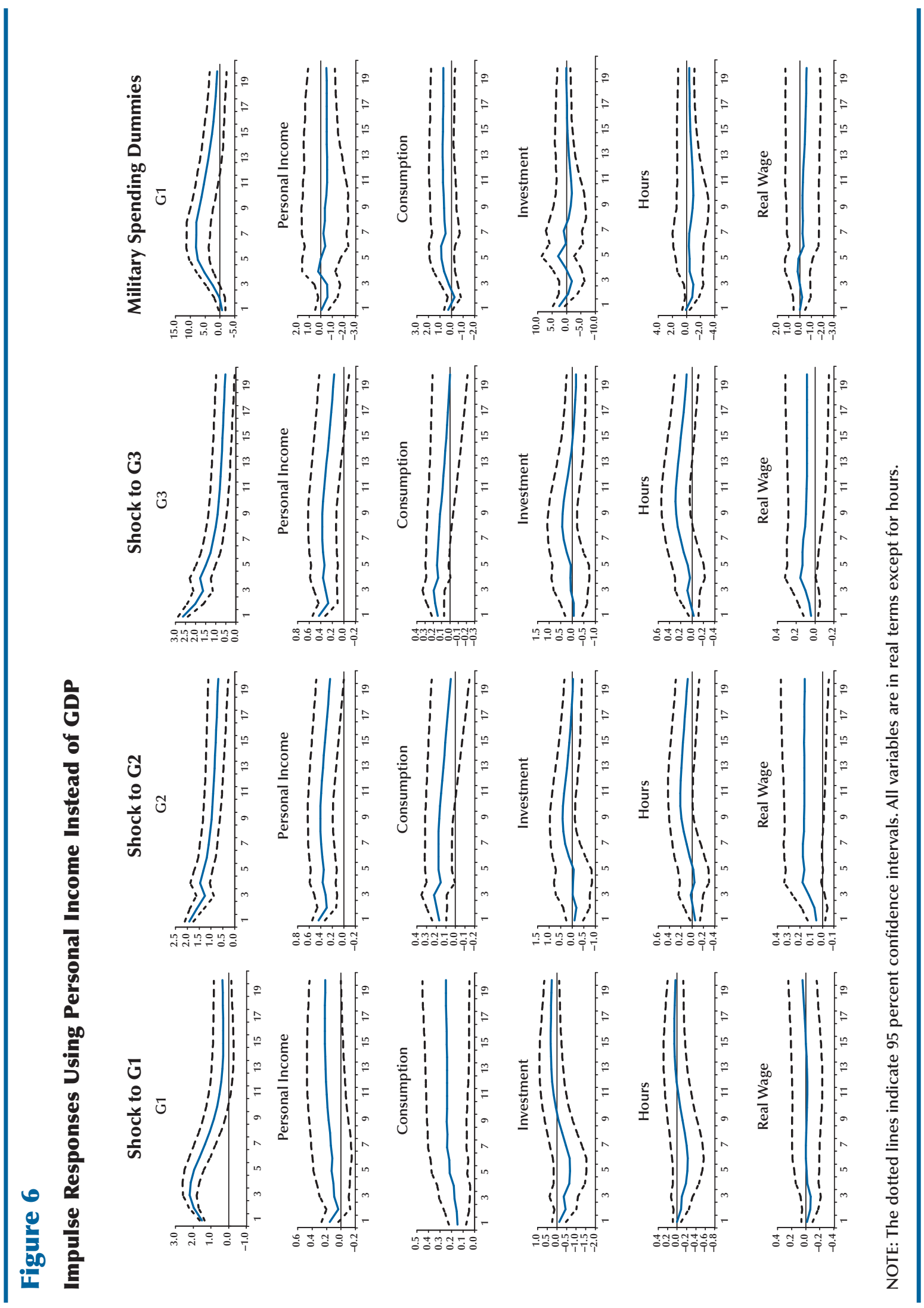




\section{Figure 7}

\section{Impulse Responses Using Federal and State/Local Government Spending}

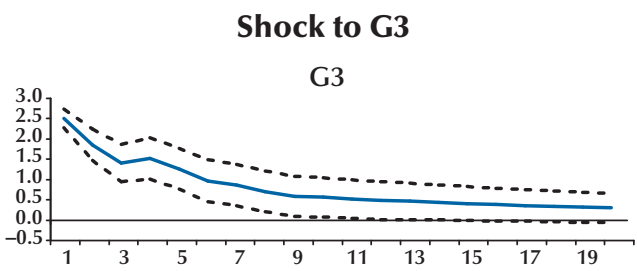

\section{Shock to State/Local Government Spending}
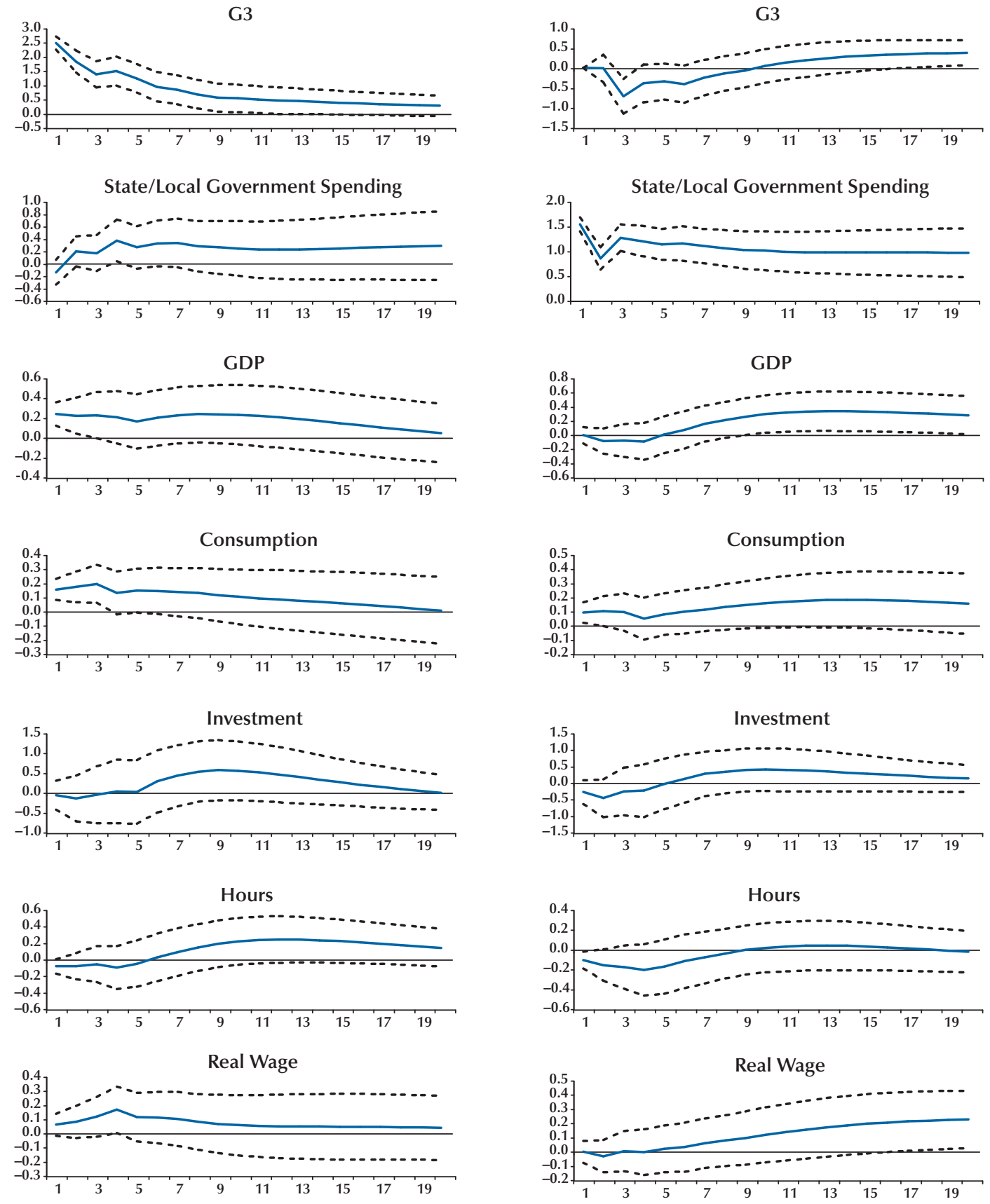

NOTE: The dotted lines indicate 95 percent confidence intervals. All variables are in real terms except for hours. 
similarly shaped; however, the magnitude of the PI response is muted.

\section{The Effect of Local Spending}

In some of the regressions above, we analyzed the effect of an increase in total government spending and the effect of an increase in federal government spending. The next logical step is to determine the effect of an increase in state and local spending. To accomplish this, we reestimate the structural VAR with both federal and state/ local spending, along with the previously mentioned economic variables. ${ }^{24}$ The series for state/ local spending is the sum of all quarterly state and local spending. ${ }^{25}$ The structural VAR identification orders federal spending first and state spending second. ${ }^{26}$ Figure 7 reports the responses of the variables to shocks to both federal and state/local spending.

The impulse responses of the system of variables remain qualitatively similar to those for the baseline model when federal and local shocks are explicitly modeled. The relevant comparison is the first column of Figure 7 to the third column of Figure 3. We include the response of local spending, which begins weakly negative but rises over time.

The second column reports the response of the system to a shock to the sum of state and local spending. Federal spending remains unaffected for the first two periods after a state-and-local shock, but then it falls, whereas GDP, investment, and hours all fall upon impact. Consumption is the only measure that rises after a shock to state and local government spending.

While looking at the effects of an increase in federal government spending versus the effects of an increase in state and local spending, it is important to consider the composition of each.

\footnotetext{
${ }^{24}$ Obviously, the military dummy identification cannot be reproduced for state and local government spending.

${ }^{25}$ In a separate paper, Owyang and Zubairy (2007) consider the effect of state and local spending shocks on their respective regions.

26 This implies that state and local spending may respond to federal spending contemporaneously but not vice versa. We could further assume that state and local spending and federal spending are determined simultaneously.
}

The major component of federal spending is defense spending, whereas state and local expenditures are primarily toward education and various public services. Therefore, federal spending shocks might be considered more exogenous and not as prone to being anticipated by the economy. With state and local spending, however, the shocks might be anticipated a quarter or two before spending actually goes up.

The two different spending aggregates might also be capturing different effects on the economy. Because state and local spending goes mostly toward public services, a positive local spending shock may not have as large a negative wealth effect. Thus, people may not feel as compelled to increase their labor supply, reducing the magnitudes of the responses of hours and output in Figure 7.

\section{CONCLUSIONS}

This paper reestablishes the conflicting predictions of identifying fiscal shocks using structural VARs versus the narrative approach using military spending dummy variables from Ramey and Shapiro (1998). Both identification schemes have strengths and weaknesses. The Ramey and Shapiro (1998) approach identifies dates of military buildup and does not require any additional identifying restrictions. However, this approach relies heavily on only four episodes in the postWorld War II era. The structural VAR approach raises questions as well. Specifically, the changes it identifies in government spending might be anticipated a few quarters before they actually occur.

We find the conflicting results of the two identifications to be generally robust to the use of alternative data series. For both identifications, using employment rather than hours produces a stronger labor market response. Using PI rather than GDP produces a weaker output response. This weaker response is mitigated if the government spending shock focuses on federal expenditures.

Finally, using the structural VAR identification only, we find that disaggregating the government spending shock may be important. Although 
the responses to federal spending shocks are, for the most part, preserved, shocks to state and local spending produce very different responses. In fact, the response of output to a state/local spending shock is negative. These results suggest that the state and local shocks may have important compositional and locational differences from the federal shocks.

\section{REFERENCES}

Blanchard, Olivier and Perotti, Roberto. "An Empirical Characterization of the Dynamic Effects of Changes in Government Spending and Taxes on Output." Quarterly Journal of Economics, November 2002, 117(4), pp. 1329-68.

Burnside, Craig; Eichenbaum, Martin; and Fisher, Jonas D.M. "Fiscal Shocks and Their Consequences." Journal of Economic Theory, March 2004, 115(1), pp. 89-117.

Edelberg, Wendy; Eichenbaum, Martin; and Fisher, Jonas D.M. "Understanding the Effects of a Shock to Government Purchases." Review of Economic Dynamics, January 1999, 2(1), pp. 166-206.

Eichenbaum, Martin and Fisher, Jonas D.M. "Fiscal Policy in the Aftermath of 9/11." Journal of Money, Credit, and Banking, February 2005, 37(1), pp. 1-22.

Fang, Lei and Rogerson, Richard. "Policy Analysis in a Matching Model with Intensive and Extensive Margins.” NBER Working Paper No. 13007, National Bureau of Economic Research, April 2007.

Fatás, Antonio and Mihov, Ilian. "The Effects of Fiscal Policy on Consumption and Employment: Theory and Evidence." Unpublished manuscript, INSEAD, August 2001.

Faust, Jon. "The Robustness of Identified VAR Conclusions about Money." Carnegie-Rochester Conference Series on Public Policy, December 1998, 49 , pp. 207-44.

Favero, Carlo and Giavazzi, Francesco. "Debt and the Effects of Fiscal Policy.” NBER Working Paper No. 12822, National Bureau of Economic Research, January 2007.
Francis, Neville; Owyang, Michael T.; and Roush, Jennifer E. "A Flexible Finite-Horizon Identification of Technology Shocks.” Working Paper No. 2005024D, Federal Reserve Bank of St. Louis, April 2007.

Mountford, Andrew and Uhlig, Harald. "What Are the Effects of Fiscal Policy Shocks?" SFB 649 Discussion Paper 2005-039, Humboldt University, Collaborative Research Center 649, July 2005.

Owyang, Michael T. and Zubairy, Sarah. "The Differential Effects of State and Federal Fiscal Policy." Unpublished manuscript, 2007.

Pappa, Evi. "New-Keynesian or RBC Transmission? The Effects of Fiscal Shocks in Labour Markets." CEPR Discussion Paper No. 5313, Centre for Economic and Policy Research, October 2005.

Paustian, Matthias. "Assessing Sign Restrictions." B.E. Journal of Macroeconomics, January 2007, 7(1), pp. 1-33.

Perotti, Roberto. "Estimating the Effects of Fiscal Policy in OECD Countries.” Working paper, Innocenzo Gasparini Institute for Economic Research, October 2004.

Perotti, Roberto. "In Search of the Transmission Mechanism of Fiscal Policy.” NBER Working Paper No. 13143, National Bureau of Economic Research, June 2007.

Ramey, Valerie A. "Identifying Government Spending Shocks: It's All in the Timing." Manuscript, University of California, San Diego, July 2006.

Ramey, Valerie A. and Shapiro, Matthew D. "Costly Capital Reallocation and the Effects of Government Spending." Carnegie-Rochester Conference Series on Public Policy, June 1998, 48, pp. 145-94.

Ravn, Morten; Schmitt-Grohé, Stephanie, and Uribe, Martín. "Deep Habits.” Review of Economic Studies, January 2006, 73(1), pp. 195-218.

Romer, Christina D. and Romer, David H. "Monetary Policy Matters." Journal of Monetary Economics, August 1994, 34(1), pp. 75-88. 
Romer, Christina D. and Romer, David H. "The Macroeconomic Effects of Tax Changes: Estimates Based on a New Measure of Fiscal Shocks." NBER Working Paper No. 13264, National Bureau of Economic Research, July 2007.

Rotemberg, Julio J. and Woodford, Michael. "Oligopolistic Pricing and the Effects of Aggregate Demand on Economic Activity." Journal of Political Economy, December 1992, 100(6), pp. 1153-207.

Sims, Christopher. "Macroeconomics and Reality." Econometrica, January 1980, 48(1), pp. 1-48.

Sims, Christopher. "Interpreting the Macroeconomic Time Series Facts: The Effects of Monetary Policy." European Economic Review, June 1992, 36(5), pp. 975-1011.

Tavares, José and Valkanov, Rossen. "Fiscal Policy and Asset Returns." Working paper, Rady School, August 2003.

Uhlig, Harald. "What Are the Effects of Monetary Policy on Output? Results from an Agnostic Identification Procedure." Journal of Monetary Economics, March 2005, 52(2), pp. 381-419.

Wagner, Gary A. and Sobel, Russell S. "State Budget Stabilization Fund Adoption: Preparing for the Next Recession or Circumventing Fiscal Constraints?" Public Choice, January 2006, 126(1-2), pp. 177-99. 


\section{DATA APPENDIX}

\begin{tabular}{|c|c|c|c|}
\hline Variable & Original series name & Source & Additional comments \\
\hline $\mathrm{G} 1^{*},+$ & $\begin{array}{l}\text { Government consumption } \\
\text { expenditures and gross } \\
\text { investment (SAAR, \$ billions) }\end{array}$ & BEA & Nominal series deflated by GDP deflator \\
\hline $\mathrm{G} 2^{*},+$ & $\begin{array}{l}\text { Government current expenditures } \\
\text { (SAAR, \$ billions) }\end{array}$ & BEA & Nominal series deflated by GDP deflator \\
\hline $\mathrm{G}^{*},+$ & $\begin{array}{l}\text { Federal government current } \\
\text { expenditures (SAAR, \$ billions) }\end{array}$ & BEA & Nominal series deflated by GDP deflator \\
\hline $\begin{array}{l}\text { State and local } \\
\text { government } \\
\text { expenditures }{ }^{*}+\end{array}$ & $\begin{array}{l}\text { State and local government } \\
\text { current expenditures } \\
\text { (SAAR, \$ billions) }\end{array}$ & BEA & $\begin{array}{l}\text { Total government current expenditures } \\
\text { less federal government current } \\
\text { expenditures }\end{array}$ \\
\hline $\mathrm{GDP}^{*,+}$ & $\begin{array}{l}\text { Gross domestic product } \\
\text { (SAAR, \$ billions) }\end{array}$ & BEA & Nominal series deflated by GDP deflator \\
\hline Personal income ${ }^{*},+$ & $\begin{array}{l}\text { Total personal income, total U.S. } \\
\text { (SAAR, \$ millions) }\end{array}$ & BEA & Nominal series deflated by GDP deflator \\
\hline Consumption ${ }^{*}+$ & $\begin{array}{l}\text { Personal consumption } \\
\text { expenditures: nondurable } \\
\text { goods (SAAR, } \$ \text { billions); personal } \\
\text { consumption expenditures: } \\
\text { services (SAAR, \$ billions) }\end{array}$ & BEA & $\begin{array}{l}\text { Sum of nominal series deflated by GDP } \\
\text { deflator }\end{array}$ \\
\hline Investment ${ }^{*},+$ & $\begin{array}{l}\text { Gross domestic investment } \\
\text { (SAAR, \$ billions); personal } \\
\text { consumption expenditures: } \\
\text { durable goods (SAAR, \$ billions) }\end{array}$ & BEA & $\begin{array}{l}\text { Sum of nominal series deflated by GDP } \\
\text { deflator }\end{array}$ \\
\hline Employment $^{+}$ & $\begin{array}{l}\text { All employees: total nonfarm } \\
\text { payrolls (SA, thousands) }\end{array}$ & BLS & \\
\hline Private employment ${ }^{\dagger}$ & $\begin{array}{l}\text { All employees: total private } \\
\text { nonfarm payrolls (SA, thousands) }\end{array}$ & BLS & \\
\hline Hours ${ }^{\dagger}$ & $\begin{array}{l}\text { Nonfarm business sector: } \\
\text { hours of all persons } \\
\text { (SA, 1992=100) }\end{array}$ & BLS & \\
\hline \multirow[t]{3}{*}{ Product wage $^{\dagger}$} & $\begin{array}{l}\text { Nonfarm business sector: } \\
\text { compensation per hour } \\
\text { (SA, 1992=100); nonfarm } \\
\text { business sector: implicit price } \\
\text { deflator (SA, 1992=100) }\end{array}$ & BLS & Deflated compensation by price deflator \\
\hline & $\begin{array}{l}\text { GDP: implicit price deflator } \\
\quad(S A, 2000=100)\end{array}$ & BEA & \\
\hline & Civilian labor force (SA, thousands) & BLS & Used to make series per capita \\
\hline
\end{tabular}

NOTE: BEA is Bureau of Economic Analysis, BLS is Bureau of Labor Statistics, SAAR is seasonally adjusted annual rate, and SA is seasonally adjusted. *Variables are in per capita terms. ${ }^{+}$We took the natural log of the series.

SOURCE: All data were obtained from Haver Analytics. 